\title{
TAKING JUdicial NOTICE OF GENOCIDE? The Problematic LaW ANd Policy of the Karemera Decision
}

\author{
Ralph Mamiya*
}

Table of Contents

I. INTRODUCTION 1

II. USE OF JUDICIAL NOTICE IN INTERNATIONAL CRIMINAL TRIBUNALS ..................................... 2

A. Clear Benefits \& Present Dangers: Judicial Notice in Domestic Legal Systems .. 3

B. JUDICIAL NOTICE DOCTRINE IN INTERNATIONAL CRIMINAL LAW ....................................... 5

1. THE INTERNATIONAL CRIMINAL TRIBUNALS: IN NEED OF EFFICIENCY ................................... 6

2. JUdicial NOTICE IN THE TRIBUNALS: RULES 94(A) AND 94(B) .............................................. 7

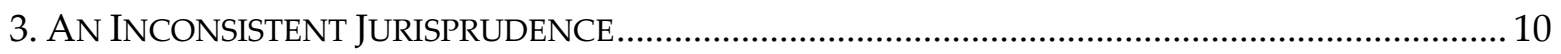

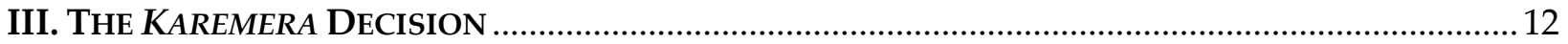

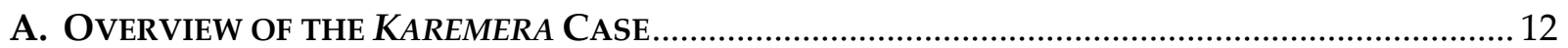

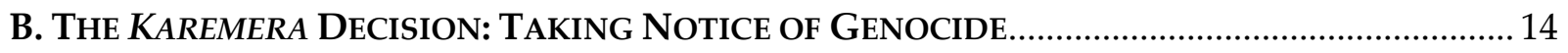

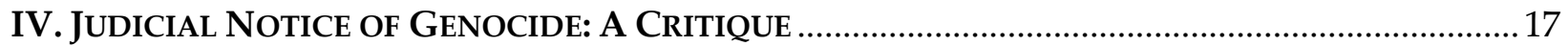

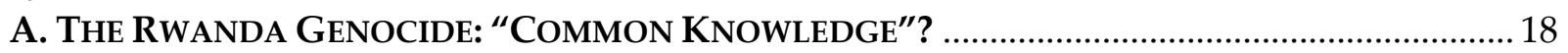

1. INTENT: CENTRAL IN ANY DEFINITION OF GENOCIDE ........................................................ 18

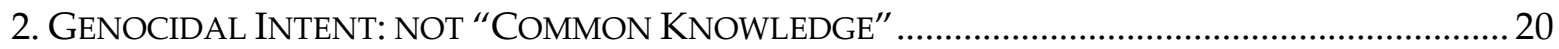

B. JUdicial Notice OF GENOCIDE AND THE CREATION OF AN HISTORICAL RECORD ............... 21

C. THE DANGER OF KAREMERA IN FUTURE CASES: THE EXAMPLE OF DARFUR ......................... 23

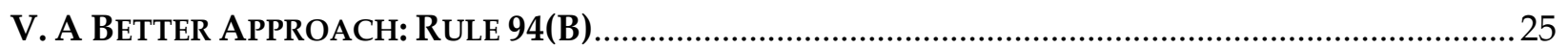

A. Rule 94(B): Providing Expediency While Avoiding Karemera's Problems ............... 26

B. DisAdVANTAGE TO Rule 94(B): CONTINUED CONTROVERSY.............................................. 26

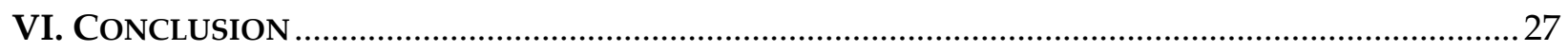

\section{Abstract}

On June 16, 2006, the Appeals Chamber of the International Criminal Tribunal for Rwanda issued a decision in Prosecutor $v$. Karemera taking judicial notice of the fact that genocide occurred in Rwanda in 1994. This decision startled many court observers. While no internationally respected commentator would today question whether the Rwanda genocide took place, should such an event be judicially noticed without evidence?

This paper examines that question, arguing that the ICTR Appeals Chamber's expansive use of judicial notice in Karemera was both illogical and unwise. Genocide, whether as an historical fact or legal charge, fails to meet the "common knowledge" standard of judicial notice. Further, taking such notice hinders the creation of an historical record and risks violating the rights of defendants. This paper proposes a solution: acknowledging genocide as a "previously adjudicated fact" under Rule 94(B).

This article - the first to critique Karemera - reviews the jurisprudence of judicial notice in the tribunals, examines the modern concept of genocide, critiques the ICTR's reasoning and proposes a practical solution that may be relevant to future international courts. This paper is particularly relevant to scholars and practitioners of international criminal law, and may be of interest to scholars of genocide and conflict studies.

\footnotetext{
* Ralph Mamiya, J.D., worked most recently with UNHCR, and from May-August 2004, he served as a legal intern with the ICTR's Office of the Prosecutor on the Karemera trial team. The views expressed in this paper are solely his own. He would like to thank Micah Williams and Leah Williams for their assistance.
} 


\section{INTRODUCTION}

On June 16, 2006, the Appeals Chamber of the International Tribunal for Rwanda (ICTR) issued a decision taking judicial notice of the fact that genocide occurred in Rwanda in $1994 .^{1}$ In accepting genocide as "common knowledge," this decision in Prosecutor v. Karemera et al. (Karemera Decision) startled many court observers. ${ }^{2}$ While no internationally respected commentator would today question whether the Rwanda genocide took place, should such an event be judicially noticed without evidence? This paper examines and answers that question.

Judicial notice is an important tool for expediting trials and, particularly in the delayplagued ICTR, it should be used more frequently. The ICTR Appeals Chamber's expansive use of judicial notice in Karemera, however, was both illogical and unwise. As argued below, the fact of genocide in Karemera fails to meet the "common knowledge" standard of judicial notice. Further, taking notice of genocide may hinder the ICTR's goal of creating an historical record. In the following paragraphs, this paper will critique the Karemera Decision and sketch an approach to judicial notice that enables reasonable expedition but guards against damaging assumptions.

Rather than treating extraordinary and complex events like genocide as "common knowledge," the ICTR and future international courts should take judicial notice of them only as "previously adjudicated facts," a separate basis for judicial notice in international criminal law.

\footnotetext{
${ }^{1}$ See Prosecutor v. Karemera et al., Case No. ICTR-98-44-AR73(C), Decision on Prosecutor's Interlocutory Appeal of Decision on Judicial Notice, ๆๆ 33-38 (June 16, 2006) [hereinafter “Karemera Decision”].

${ }^{2}$ See Rwanda: Genocide-A Notorious Event Burking the Judiciary Debate?, HIRONDELLE News AGENCY, July 11, 2006, available at http://www.hirondelle.org/arusha.nsf; Rwanda: ICTR Defendants 'Shocked' by Appeals Chamber Decision, HIRONDELle News AGENCY, June 29, 2006, available at http://www.hirondelle.org/arusha.nsf.
} 
This approach allows for a robust use of judicial notice but retains procedural safeguards and furthers the policies of fact finding that underlie international criminal fora.

While this paper has implications for all of the international and "hybrid" criminal foraincluding the ICTR, the International Criminal Tribunal for Yugoslavia (ICTY), the Special Court for Sierra Leone (Special Court), and the new International Criminal Court (ICC)—its analysis focuses upon the case law of the ICTR and ICTY (referred to hereafter as "the Tribunals"). These two institutions are controlled by the Karemera Decision, and their practices and precedents are the best established and most influential.

The second part of this paper introduces the doctrine of judicial notice, paying particular attention to international criminal law's two alternative standards for the doctrine: facts of "common knowledge" or facts that have been "previously adjudicated." Part III examines the ICTR's recent Karemera Decision, reviewing the decision's context and analyzing its legal reasoning. Part IV critiques the Karemera Decision, arguing that the intent requirement of genocide makes it difficult, perhaps impossible, to treat the fact as "common knowledge." Part IV further argues that such treatment undermines the goal of creating an historical record of atrocities. Part V proposes a better approach: treating genocide as subject to judicial notice only where it is a previously found "adjudicated fact." This approach affords the economy of judicial notice while preserving the integrity of the doctrine and remaining true to the goals of international criminal law. Part VI briefly concludes.

\section{USE OF JUdicial Notice In INTERNATIONAL CRIMINAL TRIbUNALS}

An important function of the new breed of international criminal fora is the further development of the international legal framework. Just as centuries of litigation have produced a robust legal corpus in national jurisdictions, devoting time and energy to international fora 
should serve the development of international law. ${ }^{3}$ While the ICTR and ICTY have begun to fulfill this hope in important areas, the case law of judicial notice shows that this legal development can be fraught with conflicting values and inconsistent decision making. ${ }^{4}$ This section examines the foundations of judicial notice in domestic legal systems and the emerging jurisprudence of judicial notice in international criminal law.

\section{A. Clear Benefits \& Present Dangers: Judicial Notice in Domestic Legal Systems}

Judicial notice, a legal doctrine whereby a court (rather than a jury) may accept a fact as proven with the submission of limited or no evidence, is well established in national jurisdictions. ${ }^{5}$ Judicial notice is ingrained in the jurisprudence of common law systems, and some civil law jurisdictions have adopted the doctrine as well. ${ }^{6}$

Generally, a court may employ judicial notice where the fact under review is so well known that it is not subject to reasonable dispute or can be readily and authoritatively verified. ${ }^{7}$ Classic examples of proper subjects for judicial notice are "generally known" facts, such as that "a shotgun is a dangerous weapon," "a fortnight is too short a period for human gestation," or

\footnotetext{
${ }^{3}$ SteVEn R. RATNER \& JASON S. ABRAMS, ACCOUNTABILITY FOR HuMAn RightS Atrocities IN INTERNATIONAL LAW: BEYOND THE NUREMBERG LEGACY 131-36 (2001)

${ }^{4}$ See generally, James G. Stewart, Judicial Notice in International Criminal Law: A Reconciliation of Potential, Peril and Precedent, 3 INT'L CRIM. L. ReV. 245 (2003).

${ }^{5}$ See Prosecutor v. Fofana et al., Case No. SCSL-2004-14-AR73, Decision on Appeal Against "Decision on Prosecution's Motion for Judicial Notice and Admission of Evidence"—Separate Opinion of Judge Roberts, १ๆ 3-16 (May 16, 2005) [hereinafter "Robertson Opinion"].

${ }^{6}$ See Robertson Opinion, 9ๆ 6-7; see, e.g., German Criminal Procedure Code, Section 244(3), cited in Stewart, supra note 4 , at 247 .

${ }^{7}$ See FED. R. EVID. 201 advisory committee’s note; 1-4 WeInSTEIN EVIDENCE MANUAL $§ 4.02$.
} 
that "cats are kept for domestic purposes." In addition, judicial notice has traditionally been taken of facts that are verifiable, such as dates of the Islamic calendar and established scientific principles. ${ }^{9}$

Judicial notice serves a number of important functions in legal proceedings. First, the doctrine promotes efficiency in the legal system. ${ }^{10}$ Judicial notice can allow a court to dispense with the time-consuming adversarial process, a particular benefit when the fact is something as simple as "cats are kept for domestic purposes." maintain "intellectual honesty" with regard to certain facts, such as accepting the results of established scientific tests even though many such tests have some room for error. ${ }^{12}$ Finally,

\footnotetext{
${ }^{8}$ See Dennis J. Turner, Judicial Notice and Federal Rule of Evidence 201: A Rule Ready for a Change, 45 U. PITT. L. REV. 181, 196 (1983); Carter v Eastbourne Borough Council [2000] 164 JP 273; [2000] 2 PLR 60 (QB), cited in Jonathan I. Edelstein, The Prasad Affidavits: Proof of Facts in Revolutionary Legitimacy Cases, 24 SYDNEY L. REV. 57, 66-67 (2002).

${ }^{9}$ See Prosecutor v. Sesay et al., Case No. SCSL-04-15-T, Decision on Prosecution Motion for Judicial Notice of Significant Days of the Islamic Calendar, (July 29, 2006); Edward J. Imwinkelried, Evidence Law Visits Jurassic Park: The Far-Reaching Implications of the Daubert Court's Recognition of the Uncertainty of the Scientific Enterprise, 81 IOWA L. REV. 55, 71 (1995).

${ }^{10}$ See Daryl A. Mundis, Current Development: Improving the Operation and Functioning of the International Criminal Tribunals, 94 A.J.I.L. 759, 765 (2000).

${ }^{11}$ See Bruce W. Burton, The "O.K. Corral Principle”: Finding the Proper Role for Judicial Notice in Police Misconduct Matters, 29 N.M.L. REv. 301, 312-13 (1999); Edelstein, supra note 8, at 66-67.

${ }^{12}$ See Bruce W. Burton, The "O.K. Corral" Principle in the Age of Terrorism: Proposed New Protocols for Judicial Notice in Cases on Alleged Misconduct by Law Enforcement, 41 IDAHO L. REV. 85, 91 (2004).
} 
judicial notice allows a court or system of courts to maintain a uniform interpretation of commonly reviewed facts..$^{13}$

At the same time, judicial notice presents a number of dangers. First, almost by its nature, judicial notice circumvents evidentiary standards designed to protect defendants. ${ }^{14}$ On a related issue, judicial notice may “reflect[ ] society's deep-rooted fears of crime, violence, and terrorism...."15 In some of the darker periods of the doctrine's history, courts have taken judicial notice of racist, fallacious, and widely believed propositions of white superiority to support segregation in the United States as well as apartheid in South Africa. ${ }^{16}$ Similarly, courts have taken judicial notice of highly suspect facts to provide legal justifications for coups d'etat in a number of countries. ${ }^{17}$ As one scholar wrote, "[c]ommon sense, like stereotypes, can 'masquerade as knowledge' and is both dangerous and difficult to unmask and dislodge...."18 For all of these reasons, U.S. courts have often been cautious in utilizing judicial notice. ${ }^{19}$

\section{B. JUdicial Notice Doctrine In InTERnational Criminal LaW}

This section examines the procedural details of judicial notice as practiced by the Tribunals, providing an introduction to a little-examined but increasingly important area of law.

\footnotetext{
${ }^{13}$ See Stewart, supra note 4, at 245.

${ }^{14}$ See id. at 246.

${ }^{15}$ See Burton, supra note 12 , at 86.

${ }^{16}$ See A. Leon Higginbotham, Jr., F. Leon Higginbotham \& S. Sandile Ngcobo, De Jure Housing Segregation in the United States and South Africa: The Difficult Pursuit for Racial Justice, 1990 U. ILL. L. REV. 763, 824, 867 (1990).

${ }^{17}$ See Tayyab Mahmud, Jurisprudence of Successful Treason: Coup d'Etat \& Common Law, 27 CORNELL INT'L L.J. $49,53,92-93,96,114,134$ (1994).

${ }^{18}$ See Regina Graycar, The Gender of Judgments: Some Reflections on “Bias”, 32 U.B.C. L. REV. 1, 16 (1998).

${ }^{19}$ See FED. R. EVID. 201 advisory committee's note.
} 
Section II(B)(1) reviews the judicial structure of the Tribunals and the difficulties they have faced. Section II(B)(2) then reviews the basic "black-letter law" of their judicial notice doctrines, and the final section reviews the incoherence of the doctrine's recent application.

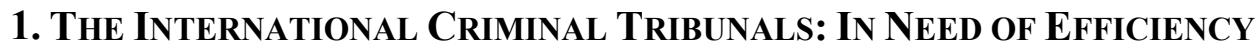

After more than a decade in operation, it is clear that both the ICTR and ICTY are in need of tools to expedite their proceedings. While critics of international criminal law often demand opposing policies and suggest differing goals, ${ }^{20}$ even ardent proponents of international justice agree that the Tribunals have at times moved too slowly. ${ }^{21}$ This dissatisfaction led the Security Council in 1998 to appoint a panel of experts (the "Expert Group") to examine the efficiency of the Tribunals' practices. ${ }^{22}$ The Expert Group found unnecessary delay, citing factors that ranged from logistical issues, such as language translation and courtroom availability, to the immaturity of international criminal law and the synthesis of varying legal traditions. ${ }^{23}$ In making its recommendations, the Expert Group's Report dedicated a special

${ }^{20}$ For instance, the ICTR has been criticized both for insufficiently respecting the rights of defendants and for handing down lenient sentences, and its acquittals have resulted in outrage. See Noel Mwakugu, Rwanda Tribunal in Turmoil, BBC, February 2, 2004, available at http:/www.globalpolicy.org; Aimable Twahirwa, Genocide Sentences “Humiliate Survivors,” MAIL \& GUARDIAN, January 10, 2006, available at http://www.globalpolicy.org; Thousands Demonstrate against UN Tribunal, ALLAFRICA, available at: http://www.globalpolicy.org.

${ }^{21}$ See, e.g., INTERNATIONAL CRISIS GROUP, INTERNATIONAL CRIMINAL TRIBUNAL FOR RWANDA: JUSTICE DELAYED (2001); Report of the Expert Group to Conduct a Review of the Effective Operation and Functioning of the International Criminal Tribunal for the Former Yugoslavia and the International Criminal Tribunal for Rwanda, U.N. Doc. A/54/634, ๆ 35 (Nov. 11, 1999) [hereinafter “Experts' Report”].

${ }^{22}$ See Experts’ Report, 19 2-4.

${ }^{23}$ See id., at $96-37,38-39,61-64,82$. 
section to the potential utility of judicial notice, finding that "further consideration should be given to greater use of judicial notice in a manner that fairly protects the rights of the accused and at the same time reduces or eliminates the need for identical repetitive testimony and exhibits in successive cases....,24

\section{JUdicial Notice IN THE Tribunals: RULES 94(A) AND 94(B)}

Judicial notice is an old doctrine, and it has a relatively long history in international criminal procedure. The International Military Tribunals at Nuremberg and Tokyo both utilized provisions for judicial notice. ${ }^{25}$ Similarly-worded examples of the doctrine also appear in the Rules of Procedure and Evidence for the ICTR, the ICTY, the Special Court, and the Statute of the $\mathrm{ICC}^{26}$

Unlike U.S. rules on judicial notice, the Tribunals and the Special Court recognize two bases for taking notice of a fact. Rule 94(A) allows for notice of "facts of common knowledge," similar to the facts "generally known" or "capable of accurate and ready determination" noticeable under U.S. Federal Rule of Evidence (“FRE”) $201 .^{27}$ In addition, Rule 94(B) allows

\footnotetext{
${ }^{24} I d$., at 985 .

${ }^{25}$ See Stewart, supra note 4, at 247-48.

${ }^{26}$ See and compare Rules of Procedure and Evidence, International Criminal Tribunal for Rwanda, at 124 (2005)

[hereinafter "ICTR Rules of Procedure and Evidence"]; Rules of Procedure and Evidence, International Tribunal for the Prosecution of Persons Responsible for Serious Violations of International Humanitarian Law Committed in the Territory of the Former Yugoslavia since 1991, IT/32/Rev. 38, at 94 (June 13, 2006), available at http://www.un.org/ [hereinafter "ICTY Rules of Procedure and Evidence"]; Rules of Procedure and Evidence of the Special Court for Sierra Leone (amended May 13, 2006), at 45, available at http://sc-sl.org; _Rome Statute if the International Criminal Court, U.N. Doc. 2187 U.N.T.S. 90, art. 69, entered into force July 1, 2002.

${ }^{27}$ See FED. R. EvID. 201.
} 
for notice of "adjudicated facts": facts that have been previously found by the Tribunal. ${ }^{28}$ As with judicial notice based on "generally known facts," Rule 94(B) judicial notice expedites proceedings and improves the uniformity of judicial decisions.

Rule 94(B) may strike some readers as questionable, even unconstitutional by American standards; indeed, the rule's introduction was controversial among Tribunal judges. ${ }^{29}$ It is, however, a judicial principle recognized in a number of jurisdictions, both common law and civil law. ${ }^{30}$ Further, the Tribunals are cognizant of the tension between Rule 94(B) and the rights of defendants. While the ICTR provides defendants with a right analogous to the American right to confrontation, its interpretation of this right balances ideals of due process against judicial economy and other factors. ${ }^{31}$

${ }^{28}$ See, e.g., ICTR Rules of Procedure and Evidence, at 124. Note that the ICTR's "adjudicated facts" are different from the FRE 201's "adjudicative facts," the latter referring to facts concerning the immediate parties and their situation (rather than "legislative" facts that the court uses in crafting precedent or judicial policies that may have broad implications); FRE 201 applies only to “adjudicative” facts. See FED. R. EVID. 201 advisory committee's note. While scholars have examined the adjudicative/legislative distinction with great care, see FED. R. EVID. 201, this paper will not review it further, as international criminal jurisprudence has not yet recognized it, and it does not bear heavily upon the instant issue.

${ }^{29}$ See, e.g., Ohio v. Roberts, 448 U.S. 56, 57 (1980) (holding that admission of out-of-court statements were admissible only when accompanied by “indicia of reliability"); Patricia M. Wald, The International Criminal Tribunal for the Former Yugoslavia Comes of Age: Some Observations on Day-to-Day Dilemmas of an International Court, 5 WASH. U. J. L. \& POL'Y 87, 111 (2001).

${ }^{30}$ See Stewart, supra note 4, at 255 (noting British, Russian and German uses of adjudicated facts).

${ }^{31}$ See S.C. Res. 955, S/RES/955, Annex: Statute of the International Criminal Tribunal of Rwanda, art. 20(4)(e) (Nov. 8, 1994) [hereinafter "ICTR Statute"]; Prosecutor v. Ntakirutimana et al., Case No.: ICTR-96-10-T, ICTR-9617-T, Decision on the Prosecutor’s Motion for Judicial Notice of Adjudicated Facts, 9 ๆ 28-29 (Nov. 22, 2001); 
While Rule 94(B) allows adjudicated facts from previous cases to be judicially noticed, the Tribunals have also placed restrictions on its use. First, a court may only notice a fact under 94(B) if that fact was previously scrutinized through a completed adversarial process. ${ }^{32}$ Thus, the court cannot notice facts that result from a guilty plea, nor voluntary admissions of fact made by a defendant during trial. ${ }^{33}$ Further, a court cannot notice facts from judgments that are under appeal. ${ }^{34}$ It is also generally agreed that "legal characterisations or legal conclusions based on an interpretation of facts" will not be noticed. ${ }^{35}$ Noticing a fact under 94(B) is also discretionary, and such discretion cannot be used to prejudice the accused." ${ }^{\prime 36}$

Perhaps most importantly, Rule 94(B) only creates a "presumption" that the fact is true, a presumption that the opposing party may challenge at trial. ${ }^{37}$ This discretionary and tentative approach of Rule 94(B) contrasts with judicial notice under Rule 94(A), where, if a fact is

Brown v. Texas, 443 U.S. 47, 50-51 (1979) (noting that the interpretation of certain rights under the U.S.

Constitution "depend on a balance between the public interest and the individual's right to personal security....").

${ }^{32}$ See Prosecutor v. Ntakirutimana et al., supra note 31, ๆ 26.

${ }^{33}$ See Prosecutor v. Nyiramashuko et al., Case No. ICTR-97-21-T, Decision on the Prosecutor's Motion for Judicial Notice and Admission of Evidence, $₫ 36$ (May 15, 2002). Note that the bar on judicial notice of voluntary admissions likely stems from civil law jurisdictions' traditional animosity towards guilty pleas and plea bargaining.

${ }^{34}$ See Prosecutor v. Zoran Kupreškic et al., Case No. Case No. IT-95-16, Decision on the Motions of Drago Josipovic, Zoran Kupreškic, and Vlatko Kupreškic to Admit Additional Evidence Pursuant to Rule 115 and for Judicial Notice to be Taken Pursuant to Rule 94(B) (May 8, 2001), 9ף 5-6 [hereafter “Kupreškic Decision”].

${ }^{35}$ See Prosecutor v. Ntakirutimana et al., supra note 31, ๆ 30.

${ }^{36} I d . \uparrow 28$.

${ }^{37}$ See Prosecutor v. Milosevic, Case No.: IT-02-54-AR73.5, Decision on the Prosecutor's Interlocutory Appeals Against the Trial Chamber's 10 April 2003 Decision on Prosecution Motion for Judicial Notice of Adjudicated Facts (Oct. 28, 2003). 
deemed "common knowledge," the Tribunal must accept it as conclusively proven. Rule 94(B) thus potentially provides greater protection for defendants' rights. As with any broad provision such as Rules 94(A) and 94(B), however, it is only through application to specific circumstances that the law takes on substance; as the next section shows, these interpretations have been far from uniform.

\section{AN INCONSISTENT JURISPRUDENCE}

The authority for the Tribunals' exercise of judicial notice comes from each Tribunal's Rules of Procedure and Evidence. The Tribunals, however, have historically been wary of judicial notice and, when employed, have used it inconsistently. As the Expert Group noted, the Tribunals' Trial Chambers' use of judicial notice was "very cautious" at best. ${ }^{38}$ Another commentator notes that certain aspects of judicial notice have been met with "reluctance and controversy," resulting in part from "dangers inherent" in the doctrine's application. ${ }^{39}$

When the ICTR's Trial Chambers have sought to exercise their powers of judicial notice, their interpretations of its scope have varied widely. ${ }^{40}$ For instance, in 1998 the Akayesu court took judicial notice of "the fact that widespread killings were perpetrated throughout Rwanda in

\footnotetext{
${ }^{38}$ See Experts’ Report, supra note 21, ๆ 85.

${ }^{39}$ Stewart, supra note 4, at 246, 274.

${ }^{40}$ See id. at 249-267 (reviewing the oft-conflicting decisions of the Tribunals regarding judicial notice). Note that the Special Court for Sierra Leone, as a recently developed "hybrid" court that has drawn almost exclusively from the common law tradition, has maintained a more consistent approach to judicial notice. See and compare, Prosecutor v. Fofana et al., Case No. SCSL-2004-14-AR73, Decision on Appeal Against “Decision on Prosecution's Motion for Judicial Notice and Admission of Evidence (May 16, 2005); Prosecutor v. Brima et al., Case No. SCSL04-16-PT, Decision on the Prosecution Motion for Judicial Notice and Admission of Evidence (Oct. 25, 2005). The Special Court has not, however, taken judicial notice of genocide or an analogous fact.
} 
1994," and the First Semanza Decision followed suit. ${ }^{41}$ Subsequent courts, however, disagreed. The ICTR's Trial Chamber II held in the Kajelijeli case that the existence of "widespread and systematic attacks" was reasonably disputable. ${ }^{42}$ The Kajelijeli court also took issue with this fact because the words "widespread and systematic attacks" were directly drawn from elements of the crimes charged, which the Prosecutor had to prove beyond a reasonable doubt. ${ }^{43}$ Later, Trial Chamber II again rejected taking judicial notice of "widespread and systematic attacks" again in the "Butare" cases. ${ }^{44}$ ICTR Trial Chamber I refused to find this fact in the Ntakirutimana and Niyitegeka cases as well. ${ }^{45}$

Another divergence of opinion is evident in decisions regarding the characterization of the conflict in Rwanda under international humanitarian law. The Semanza, Akayesu, and

${ }^{41}$ Prosecutor v. Akayesu, Case No. ICTR-96-4-T, Judgement, ๆ 114 (Sept. 2, 1998) [hereafter “Akayesu Judgement"]; Prosecutor v. Semanza, Case No. ICTR-97-20-I, Decision on the Prosecutor's Motion for Judicial Notice and Presumptions of Facts Pursuant to Rules 94 and 54, 929 (Nov. 3, 2000) [hereinafter "Semanza Decision"].

${ }^{42}$ Prosecutor v. Juvénal Kajelijeli, Case No. ICTR-98-44A-T, Decision on the Prosecutor's Motion for Judicial Notice Pursuant to Rule 94 of the Rules, (April 16, 2002), ๆ 17 [hereinafter “Kajelijeli Decision”].

${ }^{43} I d$.

${ }^{44}$ Prosecutor v. Nyiramashuko, supra note 33, $\uparrow$ 115-16 (May 15, 2002). Note that the ICTR groups certain individual accused together in sets of cases, usually based on geography (such as "Butare," the name of Rwanda's second largest city), or theme (such as the "Military" cases, which all involve military leaders). See Status of Cases, International Criminal Tribunal for Rwanda, at http://69.94.11.53/default.htm (last accessed August 9, 2006).

${ }^{45}$ See Prosecutor v. Elizaphan Ntakirutimana and Gerard Ntakirutimana, Case No. ICTR-96-10-T \& Case No. ICTR-96-17-T, Decision on the Prosecutor's Motion for Judicial Notice of Adjudicated Facts (Rule 94(B) of the Rules and Procedure and Evidence), ๆ甲 32-26 (Nov. 22, 2001); Prosecutor v. Niyitegeka, Case No. ICTR-96-14-T, Decision on Prosecutor's Motion for Judicial Notice of Facts: Rule 94 of the Rules of Procedure and Evidence, 193 6 (Sept. 4, 2002), [hereinafter "Niyitegeka Decision"]. 
"Cyangugu" courts, for instance, all readily took judicial notice of the "non-international" or “internal” nature of Rwanda's 1994 conflict. ${ }^{46}$ The Kajelijeli and Niyitegeka courts, however, declined to take judicial notice of this same fact. ${ }^{47}$

Even where the ICTR Chambers do not directly disagree, their approaches to judicial notice differ. Certain courts have completely rejected taking judicial notice of any proposition that might be construed as having legal consequences — such as the existence of "widespread of systematic attacks" or whether Rwanda was party to the Geneva Conventions - while others have readily noticed such facts. As one commentator noted before the Karemera Decision, "the sheer diversity of standards applied to the term common knowledge suggests that there is little consistent or principled application of legal tests.. ${ }^{, 48}$

\section{THE KAREMERA DECISION}

The ICTR Appeals Chamber's decision in Prosecutor v. Karemera, et al. brings some unity to the disparate interpretations of Rule 94 reviewed above. Here, we examine the doctrine that Karemera develops, although an analysis of its implications must wait for Part IV.

\section{A. Overview of The Karemera CASE}

The Karemera case, initiated in 1998 and still ongoing, involves three defendants, Édouard Karemera, Mathieu Ngirumpatse, and Joseph Nzirorera, all of whom were members of the powerful Mouvement Révolutionnaire National pour le Développement (MRND) political

\footnotetext{
${ }^{46}$ See Akayesu Judgment, 627 (finding a non-international armed conflict after taking judicial notice of certain "UN documents" as well as other admitted evidence); Semanza Decision, supra note 41, at Annex A, No. 3; Prosecutor v. André Ntagerura et al., Case No. ICTR-99-46-T, Oral Decision, (July 4, 2002), cited in Stewart, supra note 4 , at n. 17 .

${ }^{47}$ See Kajelijeli Decision, supra note 42, \ 17; Niyitegeka Decision, $₫ 6$.

${ }^{48}$ See Stewart, supra note 4, at 252.
} 
party and held posts in Rwanda's government before and during the genocide. ${ }^{49}$ In its indictment, the ICTR Prosecutor accuses the defendants of genocide, as well as crimes against humanity and serious violations of Common Article 3 of the Geneva Conventions. ${ }^{50}$

While experts seem to agree that evidence against the accused in the Karemera case is strong, ${ }^{51}$ procedural issues have slowed the trial. In addition to the often slow pace of ICTR trials, the Karemera trial lost six months of proceedings after one of the original judges recused herself and the trial was forced to begin again with a new judge. ${ }^{52}$ Thus, in the interest of hastening the new proceedings, the Karemera prosecution team submitted a motion to take judicial notice of certain facts. Among these facts, the prosecution submitted the existence of

\footnotetext{
${ }^{49}$ See ICTR Detainees - Status on 22 August 2006, International Criminal Tribunal for Rwanda, available at http://69.94.11.53/default.htm. André Rwamakuba was previously a defendant in this case but is now being tried separately. See id.; Karemera et al., Case No. ICTR-98-44, Indictment (Aug. 8, 1998); GERARD PrUnIER, THE RWANDA CRISIS: HISTORY OF A GENOCIDE 76, 126 (1997).

${ }^{50}$ See Prosecutor v. Karemera, et al., Case No. ICTR-98-44-I, Amended Indictment, at 1 (February 23, 2005).

${ }^{51}$ Some experts, for instance, have named Nzirorera and Ngirumpatse as key players in the genocide. See PRUNIER, supra note 49, at 240; LindA MELVERn, CONSPIRACY to MuRdER: THE RWANDAN GENOCIDE 117-18 (2004).

${ }^{52}$ See Prosecutor v. Karemera et al., Case No.: ICTR-98-44-T, Decision on Motions by Nzirorera and Rwamakuba for Disqualification of Judge Vaz, $\uparrow \uparrow$ 1-4 (May 17, 2004); Prosecutor v. Karemera et al., Case No.: ICTR-98-44-T, Decision on Motion by Ngirumpatse for Disqualification of Judge Vaz, 11 (May 17, 2004); Prosecutor v. Karemera et al., Case No. ICTR-98-44-AR15bis.2, Decision on Interlocutory Appeals Regarding the Continuation of Proceedings with a Substitute Judge and on Nzirorera's Motion for Leave to Consider New Material, ๆๆ 1-3, 55-60
} (Oct. 22, 2004). 
genocide in Rwanda for notice under Rule 94(A), arguing that the genocide was "common knowledge" and well documented..$^{53}$

The Karemera Trial Chamber rejected taking judicial notice of the Rwanda genocide. ${ }^{54}$ In its decision, the Karemera Trial Chamber offered two strangely contradictory arguments. First, it argued that the fact that a genocide occurred in Rwanda was irrelevant because such an event did not have any bearing on the accused's guilt; after all, noticing such a fact would not relieve the prosecution's burden of proving particular murders and the accused's responsibility. ${ }^{55}$ Then, in a brief line that drew on the rationale of the Semanza court, the Karemera Trial Chamber argued that taking notice of genocide would improperly relieve the prosecution of its burden of proving the accused's responsibility. ${ }^{56}$

\section{B. The Karemera Decision: TaKing Notice OF GenOCIDE}

The Karemera Trial Decision was not the last word. The ICTR allows interlocutory appeals, and such an appeal was made.$^{57}$ In the resulting Karemera Decision, the Trial Chamber's rejection of judicial notice for genocide was reversed. ${ }^{58}$ Specifically, the Appeals Chamber directed the Trial Chamber to take judicial notice of the fact that "[b]etween 6 April

\footnotetext{
${ }^{53}$ See Karemera Decision, qฯ 33-34.; Prosecutor v. Karemera et al., Case No.: ICTR-98-44-PT, Motion for Judicial Notice of Facts of Common Knowledge and Adjudicated Facts, ๆๆ 3, 28 (June 30, 2005) [hereinafter "Prosecution Motion"].

${ }^{54}$ Prosecutor v. Karemera et al., Case No. ICTR-98-44-R94, Decision on Prosecution Motion for Judicial Notice: Rule 94 of the Rules of the Procedure and Evidence, 97 (Nov. 9, 2005) [hereinafter “Karemera Trial Decision”]. ${ }^{55} I d$.

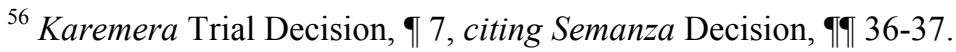

${ }^{57}$ See ICTR Rules of Procedure, at 92.

${ }^{58}$ See generally, Karemera Trial Decision.
} 
1994 and 17 July 1994, there was a genocide in Rwanda against the Tutsi ethnic group." ${ }^{\text {59 }}$ The Appeals Chamber took notice of this fact under Rule 94(A), holding that "[t]he fact of the Rwanda genocide is a part of world history, a fact as certain as any other, a classic instance of a 'fact of common knowledge."

The Karemera Decision is broadly important because it is the Appeals Chamber's most significant, authoritative and substantive analysis of judicial notice to date. ${ }^{61}$ It is also the first time that an international criminal fora—be it a Trial or Appellate body—has taken judicial notice of the existence of genocide. While the ICTR, through adversarial proceedings in other cases, had previously found the fact that genocide took place in Rwanda in $1994,{ }^{62}$ no Chamber had taken direct judicial notice of that fact. Indeed, some ICTR Chambers had expressly rejected noticing such a fact. ${ }^{63}$

The Appeals Chamber's decision was based on three general principles, each addressing the conflicted rationale in the lower court's decision. First, Karemera accepted that a judicially noticed fact may bear upon an accused's criminal responsibility, though it upheld the doctrine that such a fact could not itself be sufficient for finding an accused guilty. ${ }^{64}$ As the court noted,

${ }^{59}$ See Karemera Decision, 9 57; Prosecution Motion, supra note 53, at Annex A.

${ }^{60}$ Karemera Decision, 935.

${ }^{61}$ See and compare Prosecutor v. Niyitegeka et al., Case No. ICTR-96-14-A, Reasons for Oral Decision Rendered 21 April 2004 on Appellant's Motion for Admission of Additional Evidence and for Judicial Notice, ףศ 14-17 (May 17, 2004); Prosecutor v. Milosevic, Case No. IT-02-54-AR73.5, Decision on the Prosecution's Interlocutory Appeal Against the Trial Chamber's 10 April 2003 Decision on Prosecution Motion for Judicial Notice of Adjudicated Facts (Oct. 28, 2003); Kupreškic Decision, Ф甲 6, 12.

${ }^{62}$ See, e.g., Akayesu Judgment, supra note 41, ๆ 112-29.

${ }^{63}$ See Semanza Decision, supra note 41, ๆ 36-37.

${ }^{64}$ See Karemera Decision, ๆ 47-48. 
only relevant facts may be admitted pursuant to Rule 94, and any relevant fact will bear in some way on the accused's criminal responsibility. ${ }^{65}$ Thus, to reject judicial notice of facts because they bear on an accused's responsibility makes little sense if interpreted too broadly.

Second, the Appeals Chamber held that a court may notice "common knowledge" facts under Rule 94(A), regardless of whether the description of the "fact" coincides with phrases that have legal meaning. ${ }^{66}$ For instance, the Karemera Court took notice of the fact that there were "widespread and systematic attacks" in Rwanda in 1994, even though "widespread and systematic attacks" are an element of Crimes Against Humanity. ${ }^{67}$ This principle may appear to relieve the prosecution's burden of proving that element of the crime, but accepting that such attacks generally occurred in the country still requires the prosecutor to prove that the accused is linked in particular ways to particular attacks. Further, the Appeals Chamber held that the fact of genocide — generally — could be relevant to a case even if it was only "background" information. ${ }^{68}$ Thus, the Chamber argued, the existence of a genocide in Rwanda could provide important context while not constituting evidence that any accused was culpable.

At this point, the reader may recognize that the Karemera precedents appear to support the conclusion that the Rwanda genocide is a proper fact for judicial notice. While taking judicial notice that genocide occurred may bear on the accused's guilt, the effect is at best indirect. Further, the mere fact that the word "genocide" describes a legal crime should not exclude it from being judicially noticed if it is merely used to describe a set of circumstances and

\footnotetext{
${ }^{65}$ See id.

${ }^{66}$ See Karemera Decision, \ 29.

${ }^{67}$ See id. $ๆ$ 29-31; ICTR Statute, at art. 3.

${ }^{68}$ See Karemera Decision, $₫ 37$.
} 
would not alleviate the prosecutor of the burden of proving the accused's responsibility. Finally, the Karemera court held that genocide is relevant as background context.

These precedents are important because many of the diverging decisions in the Tribunals' judicial notice cases have turned on these issues of a submitted fact's "legal character" or its "bearing upon an accused's criminal responsibility." For instance, the Tribunal Chambers' varying decisions on whether the occurrence of "widespread and systematic attacks" or the "noninternational" nature of the conflict were proper subjects of judicial notice often hinged on the weight a Chamber gave to the fact's "legal character" or its bearing on an accused's guilt. ${ }^{69}$ As the next section argues, however, the principles established in Karemera should not have led the court to take judicial notice of genocide.

\section{Judicial Notice of Genocide: A CRITIQUe}

The above precedents unify a confused area of law and demarcate boundaries for subsequent courts to follow. This section will argue, however, that some of these precedents are flawed and should not compel a court to follow Karemera in taking judicial notice of genocide. Section IV(A) argues that the Rwandan genocide should not be considered "common knowledge," thus failing to meet the standard for Rule 94(A). Further, section IV(B) argues that taking judicial notice of genocide as common knowledge impedes the creation of an historical record and thus is unwise regardless of whether it is legally sound.

Before continuing, however, it is important to clarify that arguing that genocide is not "common knowledge" or is not a proper subject for judicial notice should not be construed as supporting those who deny would the existence of such massive atrocities. It is a sad but perhaps unsurprising fact that the horrific nature of genocides leads many in regions where they occur to

\footnotetext{
${ }^{69}$ See Semanza Decision, supra note 41, ๆ 42; see also Prosecutor v. Nyiramashuko et al. supra note 33, 939.
} 
deny their existence. ${ }^{70}$ The crime of genocide—indeed, any crime — need not be "common knowledge" for a court to find that it occurred and to punish the perpetrators. In fact, it will be argued in the following paragraphs that excluding genocide from judicial notice actually strengthens a court's final judgment.

\section{A. THE RWANDA GENOCIDE: “COMMON KNOWLEDGE"?}

Is the Rwanda Genocide "common knowledge"? It is, after all, one of the best-known humanitarian tragedies in history and has become synonymous with the depths of human cruelty. Nonetheless, this section argues that this notoriety has only been reached through investigations that must be verified and that important aspects of the events in Rwanda are not common knowledge.

\section{INTENT: CENTRAL IN ANY DEFINITION OF GENOCIDE}

To decide whether the Rwanda genocide was common knowledge, we need to ask what "genocide" means. Unlike the meaning of many words, which are obscured by layers of history and inconsistent usage, the recent vintage of "genocide" makes its meaning much clearer. As recently as 1941, genocide was, in the words of Winston Churchill, "a crime without a name."”1 By the mid-1940's, however, jurist Raphael Lemkin coined the term, and its concept remains heavily influenced by his work. ${ }^{72}$ Lemkin defined genocide as a "coordinated plan of different

\footnotetext{
${ }^{70}$ See Samantha Power, “A Problem From Hell”: America AND the Age Of Genocide 501 (2003).

${ }^{71}$ Winston S. ChURChILl, 3 The ChURChILl PAPers: The EVER-Widening WAR 32 (2000), cited in Power, supra note 70 , at 29 .

${ }^{72}$ See POWER, supra note 70, at 17-86 (detailing Lemkin's development of the concept of genocide and his long struggle to achieve international acceptance of genocide as an international crime).
} 
actions aiming at the destruction of the essential foundations of the life of national groups, with the aim of annihilating the groups themselves.",73

By 1946, the United Nations General Assembly initiated the process of drafting and passing the Convention on the Prevention and Punishment of the Crime of Genocide ("the Genocide Convention"). ${ }^{74}$ Under this convention, "genocide means any of the following acts committed with intent to destroy, in whole or part, a national, ethnical, racial or religious group, as such...."75 This definition was copied in large part in the ICTR, ICTY and Special Court codifications of the crime of genocide ${ }^{76}$ The International Criminal Court's Elements of Crimes also provides more detailed definitions of particular aspects of genocide. ${ }^{77}$

One may recognize from the above history that the general concept of "genocide" and the legal character of "genocide" are tightly interwoven. Indeed, unlike older concepts such as "slander," the legal and "general" uses of "genocide" may be inseparable. Nonetheless, even assuming that there is a non-legal idea of genocide, such an idea would almost certainly have an important commonality with its legal reflection: the significance of intent. Merriam-Webster, for

\footnotetext{
${ }^{73}$ RAPHAEL LEMKIN, AXIS RULE IN OCCUPIED EUROPE: LAWS OF OCCUPATION, ANALYSIS OF GOVERNMENT, PROPOSALS FOR REDRESS (1944), cited in POWER, supra note 70, at 43 [original emphasis removed].

${ }^{74}$ See G.A. Res. 96(I), U.N. Doc. A/64/Add. 1, at 188-89 (1946); RATNER \& ABRAMS, supra note 3, at 27.

${ }^{75}$ Convention on the Prevention and Punishment of the Crime of Genocide, 78 U.N.T.S. 277, entered into force Jan. $12,1951$.

${ }^{76}$ See Statute of the International Tribunal for the Prosecution of Persons Responsible for Serious Violations of International Humanitarian Law Committed in the Territory of the Former Yugoslavia since 1991, art. 4, U.N. Doc. 2/25704 at 36, annex (1993) and 2/25704/Add.1 (1993), adopted by Security Council on May 25, 1993, U.N. Doc.
} S/RES/827 (1993); ICTR Statute, at art. 2; Statute of the Special Court for Sierra Leone, 2178 U.N.T.S. 138, 145 (2002).

${ }^{77}$ See Elements of Crimes, ICC-ASP/1/3, art. 6 (2002). 
instance, defines genocide as "the deliberate and systematic destruction of a racial, political or cultural group." ${ }^{, 78}$ Thus, whether one relies on a "legal characterization," such as those used by the Tribunals, or a less legal definition, genocide always requires the intent to eradicate a population. As the Krstic court noted, "[g]enocide is one of the worst crimes known to humankind, and its gravity is reflected in the stringent requirements of specific intent. Convictions for genocide can be entered only where intent has been unequivocally established." ${ }^{, 79}$

\section{GENOCIDAL INTENT: NOT "COMMON KNOWLEDGE"}

The centrality of intent poses difficulties for accepting genocide as a commonly known fact. As one expert noted, "intent to commit a crime is generally hard to prove, and intent to commit genocide is even harder." ${ }^{\circ 0}$ While the acts that constitute genocide may be "generally known" by a community, it is rare, perhaps impossible, that such a community can have such knowledge of the intent required for genocide. Admittedly, the use of radio and public speakers to widely disseminate the hate-filled messages of "Hutu Power" made the intent behind the Rwanda genocide clearer than most. Nonetheless, the kind of evidence that a prosecutor would submit to prove specific intent—official memoranda; the testimony of experts, victims and informants; a comprehensive investigation — is rarely available to a community at large except through rumor and published accounts. Without substantial evidence, a community may make correct assumptions about intent, but such assumptions are hardly the kind of indisputable propositions for which judicial notice is generally reserved.

\footnotetext{
${ }^{78}$ Merriam Webster Online Dictionary, available at: http://www.m-w.com.

${ }^{79}$ Prosecutor v. Krstic, Case No. IT-98-33-A, Judgment, 134 (April 19, 2004).

${ }^{80}$ POWER, supra note 70 , at 7 (emphasis added).
} 
Further, when one examines the logic of the Appeals Chamber's decision in Karemera, there is little evidence that genocide is a "commonly known" fact. The Karemera court, for instance, cited "countless books, scholarly articles, media reports, U.N. reports and resolutions, national court decisions, and government and NGO reports" as "unanimously and decisively" confirming the genocide. ${ }^{81}$ While such documents collectively make a strong case for the Rwanda genocide, their combined weight does not transform a once-contestable proposition into a fact that the court may now declare to be "common knowledge." As the Semanza Court held, "Notwithstanding the over-abundance of official reports, including United Nations reports confirming the occurrence of genocide, this Chamber believes that the question is so fundamental, that formal proofs should be submitted bearing out [its] existence...." ${ }^{82}$ Indeed, the very deluge of reports suggests that the events in question are not common knowledge, that they are complex issues that a court should review evidence to decide.

Further, while many human rights advocates adopt a prosecutorial approach that focuses on the orchestration of the Rwandan genocide by a handful of political and military leaders, alternate interpretations exist. Jared Diamond points to the overpopulation and competition for scarce resources in Rwanda, arguing that many of the killings were motivated by property disputes rather than pure ethnic hatred. ${ }^{83}$ This theory does not necessarily contradict a conclusion of genocide or ameliorate culpability, but it does underscore the difficulty and complexity of discerning intent.

\section{B. JUdiCiAl Notice OF GENOCide AND THE CREATION OF AN Historical ReCORD}

\footnotetext{
${ }^{81}$ Karemera Decision, $\uparrow 35$.

${ }^{82}$ Semanza Decision, supra note 41, ๆ 36.

${ }^{83}$ See Jared Diamond, Collapse: How Societies Choose to Fail or Succeed 311-28 (2005).
} 
In addition to being a legally questionable practice, taking judicial notice of genocide as "common knowledge" fails to meet the policy goals of international criminal law. One of the most fundamental goals of international criminal fora is to establish a history of the events that they examine. ${ }^{84}$ As noted above, genocide denial is regrettably popular in nations where genocides have occurred, and setting out an impartial, detailed, and well-publicized record of atrocities is one of the most important ways to combat such denials. ${ }^{85}$ While many scholars have noted that truth commissions or similar institutions advance reconciliation and the creation on an historical narrative more effectively than criminal trials, ${ }^{86}$ establishing an authoritative record of atrocities is still an important function of international courts.

Merely taking judicial notice of genocide because it is "common knowledge" is not an effective way of creating a strong historical record. As argued above, it is unclear what facts can or should follow from judicial notice of genocide, and thus such notice does a poor job of constructing a clear historical record.

While the ICTR has already found genocide in numerous cases, ${ }^{87}$ and thus a strong historical record is already established, Karemera remains a problematic decision. An important function of the Tribunals is the development of international criminal law; if the Karemera

\footnotetext{
${ }^{84}$ RATNER \& ABRAMS, supra note 3, at 155; but see Jose Alvarez, Crimes of State/Crimes of Hate: Lessons from Rwanda, 24 YALE INT'L L. J. 365 (1999) (questioning the Tribunals' role in establishing an historical record).

${ }^{85}$ See POWER, supra note 70, at 500-01.

${ }^{86}$ See, e.g., Michael P. Scharf \& Ahran Kang, Errors and Missteps: Key Lessons the Iraqi Special Tribunal Can Learn from the ICTY, ICTR and SCSL, Case Research Paper Series in Legal Studies: Working Paper 05-33, at 9 (2005), available at http://law.case.edu/ssrn.

${ }^{87}$ See, e.g. Prosecutor v. Niyitegeka, Case No. ICTR-96-14-T, Judgment, ๆๆ 394-96 (May 16, 2003); Akayesu Judgment, ๆף 112-129.
} 
precedent is adopted by future courts in cases where the historical records are less developed, taking notice of genocide as merely "common knowledge" may have undesirable results. ${ }^{88}$ In addition, it may strike some community members as summarily unfair that a court "convicts" their country of genocide without properly submitted evidence. When backed by an evidentiary record, a conclusion of genocide can have a powerful, and hopefully beneficial, effect. When such conclusions are reached without evidence, they will almost certainly draw accusations of unfairness and do little to advance a court's authority.

\section{The Danger of Karemera In Future CaSes: The Example OF DARfur}

Applying the Karemera approach to a current situation will help to elucidate the above argument. This section will thus examine the present situation in the Darfur region of Sudan and ask whether judicial notice of genocide would be advisable in a future trial. Darfur shows that genocide is often a contestable fact and that taking judicial notice of genocide risks hindering the establishment of an historical record.

While Rwanda may be the best-known humanitarian tragedy of the second half of the Twentieth Century, Darfur may garner that dubious distinction for the first half of the TwentyFirst. Since the conflict in Darfur began in 2003, almost two million people have been displaced, and the number of dead may exceed four hundred thousand. ${ }^{89}$ One of the foremost experts on Sudan has described Darfur as "defined by ubiquitous abuse and human suffering." 90

In addition, many perpetrators of this violence appear to have the requisite intent for genocide. While the conflict in Darfur has many root causes, the conflict is often characterized

\footnotetext{
${ }^{88}$ RATNER \& ABRAMS, supra note 3 , at 131-36.

${ }^{89}$ See Jeffrey Gettleman, Toll of Darfur Underreported, Study Declares, N.Y. TIMES, Sept. 15, 2006.

${ }^{90}$ JULIE Flint \& AlEX DE WAAL, DARFUR: A SHORT History OF A LONG WAR xiii (2005).
} 
as "Arab" Sudanese militias attacking "African" Sudanese civilians on racial or ethnic grounds. This situation has convinced many that genocide is in fact being committed in Darfur. The U.S. Congress passed a declaration in 2004 finding that the Darfur situation amounted to genocide, and Secretary of State Colin Powell agreed with this finding. ${ }^{92}$

While these declarations of genocide were historic, the issue remains contentious.

Human Rights Watch has only gone so far as to call the situation in Sudan "ethnic cleansing." Further, a U.N.-appointed committee on Darfur ("Darfur Commission") reached a different conclusion from the U.S. Congress and Secretary of State. The Darfur Commission found that "the Government of Sudan has not pursued a policy of genocide," because "the crucial element of genocidal intent appears to be missing." ${ }^{94}$ At the same time, however, the Darfur Commission confusingly noted that "individuals, including Government officials, may commit acts with genocidal intent. Whether this was the case in Darfur... is a determination that only a competent court can make...."95 The Commission's report may not convince everyone—one scholar called

91 See id. at 46-50, 57-58, 66--74, 92-93; International Commission of Inquiry on Darfur, Report of the International Commission of Inquiry to the United Nations Secretary-General, ๆ 60 (Jan. 25, 2005) [hereinafter "ICID Report"]. The militias in question, generally known as the "Janjawiid," are ethnically distinguishable from many of their victims; many attacks are accompanied by racial/ethnic slurs that draw on an ideology of "Arab" superiority. It is also fairly well established that the Janjawiid have been used as a proxy force for the government of Sudan. See ICID Report, ๆ 191-93; FLINT \& DE WAAL, supra note 90, at 39-41, 49-53, 101-06, 130.

${ }^{92}$ See See S.2781, $108^{\text {th }}$ Congress, $2^{\text {nd }}$ Session, Comprehensive Peace in Sudan Act of 2004 (2004); Powell Declares Genocide in Sudan, BBC NEws, Sep. 9, available at http://news.bbc.co.uk.

93 See generally, Human Rights WATCH, DARFUR DESTROYED: ETHNiC ClEANSING By GOVERNMENT AND MiLitia FORCES IN WESTERN SUDAN (May 7, 2004), available at: http://hrw.org/reports/2004/sudan.

${ }^{94}$ ICID Report, $₫ 4$.

${ }^{95}$ Id. at 4. 
its failure to find genocide "unfathomable" ${ }^{96}$ — but such uncertainty reveals Karemera's problems. Even in the face of massive atrocities, genocide is not always clear, much less “common knowledge."

Further, the case of Darfur highlights the importance of creating a strong historical record. While human rights advocates have convinced many people around the world that massive atrocities are being committed in Darfur, Sudanese citizens may not share such a uniform view. The Sudan government's statements about Darfur range from justifications of sovereignty and the right to quell rebellion to accusations of international conspiracy; ${ }^{97}$ if such comments are even partially integrated into the eventual Sudanese historical narrative, Darfur "denial" could easily result. Sudan's numerous political fissures, the complexity of the current situation in Darfur, and the government's control over media only increase this possibility. Where the legal characterization of a factual situation is unclear, establishing a strong historical record becomes even more important. Thus, such a record becomes particularly important in Darfur, where skepticism of international accusations appears rife.

\section{A Better Approach: Rule 94(B)}

While taking judicial notice of genocide as "common knowledge" is both legallyquestionable and poor policy, such notice has undeniable advantages. As discussed above, judicial notice can expedite proceedings, a feature particularly valuable in the Tribunals. There is, however, a better approach: taking judicial notice of genocide under Rule 94(B).

\footnotetext{
${ }^{96}$ See David Luban, Calleing Genocide by its Rightful Name: Lemkin's Word, Darfur, and the UN Report, 7 ChICAGO J. INT’L L. 1, 14 (2006).

${ }^{97}$ See Sudan's Government Denies Accusations of Deliberate Killing in Darfur, PEOPLE's DAILy OnLINE, Nov. 26, 2006, available at: http://english.people.com.cn; Sudan Legislator Sees Conspiracy in UN Move for Darfur Mission, INT'L HERALD TRIBUNE, Sept. 12, 2006, available at http://www.iht.com.
} 


\section{A. Rule 94(B): Providing Expediency While Avoiding Karemera's Problems}

As reviewed in section II(B), judicial notice under Rule 94(B) allows a court to take previously adjudicated facts into evidence. Thus, where a Tribunal has already found genocide based on evidence, that Tribunal may take judicial notice of genocide. Further, Rule 94(B) provides the parties with an opportunity to be heard. Thus, if the instant defendant is in a different position from the defendant in the previously adjudicated case with regard to the submitted fact, he may argue that the matter has not been properly addressed and preserve his right to confrontation. In addition, by referencing genocide in a particular case where specific facts are found, Rule 94(B) provides a concrete factual context rather than Rule 94(A)'s more opaque notion of genocide "in general." Rule 94(B) also allows at least one court to properly find the submitted fact, establishing the foundations for a stronger historical record. Using Rule 94 (B) both allows a court to expedite trials and resolves the difficulties inherent in taking judicial notice of genocide as "common knowledge" under Rule 94(A). Finally, as an established rule in the ICTR, ICTY and Special Court, Rule 94(B) could easily be employed by those courts.

\section{B. Disadvantage to Rule 94(B): Continued Controversy}

While applying Rule 94(B) rather than 94(A) to a case like Karemera has numerous advantages, there is one disadvantage to note: $94(\mathrm{~B})$ is still controversial in some circles. Respected judges have issued dissenting opinions that express frustrations with Rule 94(B). ${ }^{98}$ In addition, a rule similar to Rule 94(B) has not yet been adopted by the ICC. Nonetheless, current

\footnotetext{
${ }^{98}$ See Prosecutor v. Milosevic, Case No. IT-02-54-AR73.5, Decision on the Prosecutor's Interlocutory Appeal against the Trial Chamber's 10 April 2003 Decision on Prosecution Motion for Judicial Notice of Adjudicated Facts-Dissenting Opinion of Judge David Hunt (Oct. 28, 2003).
} 
Tribunals have developed the jurisprudence of Rules 94(A) and 94(B), and there is little indication that the integrity of proceedings has suffered. Further, the ICC will likely face the problems of logistics, translation, and differing legal styles and will require tools for efficiency. Rule 94(B) is an important such tool, and thus its prospects are little dimmed by the current disagreement.

\section{CONCLUSION}

Judicial notice of "common knowledge" facts is an important legal tool, particularly for courts such as the Tribunals that have faced difficulties in the timely adjudication of cases. At the same time, genocide is an inappropriate fact for notice as "common knowledge." Genocide's intent requirement is nearly impossible to determine based on generally available information. Further, treating genocide as a "commonly known" fact runs counter to the fact-finding purpose of the Tribunals and may slow the development of a strong historical record. Given the importance of the ICTR in developing international criminal law, the Karemera Decision is a potentially dangerous precedent.

Fortunately, there is an alternative in Rule 94(B), which retains the benefits of the Karemera approach but solves its shortcomings. Taking judicial notice of genocide as an "adjudicated fact" under Rule 94(B) allows a court to expedite its proceedings while retaining the integrity of its procedure and developing a proper historical record. Although Rule 94(B) has not yet achieved complete acceptance, its jurisprudence is strong and its advantages clear. 